\title{
GEMIN2 wt Allele
}

National Cancer Institute

\section{Source}

National Cancer Institute. GEMIN2 wt Allele. NCI Thesaurus. Code C114434.

Human GEMIN2 wild-type allele is located in the vicinity of $14 q 13$ and is approximately 23 $\mathrm{kb}$ in length. This allele, which encodes gem-associated protein 2 , plays a role in the formation of the spliceosome. 